\title{
Productivity and nutritional value of elephant grass BRS Canará forage $^{1}$
}

\section{Produtividade e valor nutricional da forragem de capim-elefante BRS Canará}

\author{
Eduardo André Ferreira ${ }^{2 *}$; Joadil Gonçalves de Abreu ${ }^{3}$; Junio Cesar Martinez; \\ Ricardo Santos Silva Amorim 3 ; Arthur Behling Neto ${ }^{5}$; Carlos Eduardo Avelino \\ Cabral $^{6}$; Thiago Gomes dos Santos Braz ${ }^{7}$; Carlos Alberto Silva Júnior ${ }^{8}$; \\ Daniel Paulo Ferreira9
}

\begin{abstract}
The goal was to determine the ideal cutting age of elephant grass BRS Canara for forage production in the dry and rainy seasons. The experimental design comprised randomized blocks, with five treatments $(42,56,70,84$, and 98 days in the dry season and 42, 60, 76, 91, and 105 days of regrowth in the rainy season) and four replications each. Agronomic, morphological, and chemical characteristics were evaluated. In the dry season, there was a significant quadratic response for plant height and leaf blade length. For the other characteristics, a significant linear response was observed, except stem diameter. In the rainy season, a quadratic response for the leaf blade length, leaf blade width, and leaf:stem ratio was observed. For the other characteristics, there was a significant linear effect, except for the percentage of dead material. In the dry season, a verified linear response was observed for the chemical characteristics, except neutral detergent insoluble protein. In the rainy season, a linear response was verified for all evaluated characteristics, except acid detergent insoluble protein. Elephant grass BRS Canará for forage production should be cut between 70 and 85 days in the dry season and between 60 and 70 days of regrowth in the rainy season.
\end{abstract}

Key words: Forage yield. Harvest season. Morphological composition. Pennisetum purpureum.

\section{Resumo}

Objetivou-se determinar a idade de corte ideal do capim-elefante BRS Canará para produção de forragem no período da seca e das águas. O delineamento experimental foi em blocos casualizados,

1 Parte da dissertação de mestrado do primeiro autor.

2 Extensionista Rural, Empresa Mato-Grossense de Pesquisa, Assistência e Extensão Rural, EMPAER, Cuiabá, MT, Brasil. E-mail: eduardoagritrop@gmail.com

3 Profs., Programa de Pós-Graduação em Agricultura Tropical, Universidade Federal de Mato Grosso, UFMT, Cuiabá, MT, Brasil. E-mail: joadil@terra.com.br; rsamorim@ufmt.br

4 Prof., Universidade do Estado de Mato Grosso, UNEMAT, Pontes e Lacerda, MT, Brasil. E-mail: martinez1178@hotmail.com

5 Prof. UFMT, Sinop, MT, Brasil. E-mail: arthur_behling@hotmail.com

6 Prof. UFMT, Rondonópolis, MT, Brasil.E-mail: carlos.eduardocabral@hotmail.com

7 Prof., Universidade Federal dos Vales do Jequitinhonha e Mucuri, UFVJM, Diamantina, MG, Brasil. E-mail: thiagogsbz@, hotmail.com

8 Discente do Curso de Graduação em Agronomia, UFMT, Cuiabá, MT, Brasil. E-mail: carlos.alberto-sj@hotmail.com

9 Discente do Curso de Mestrado, Programa de Pós-Graduação em Agricultura Tropical, UFMT, Cuiabá, MT, Brasil. E-mail: daniel.agromatogrosso@gmail.com

* Autor for correspondence 
com cinco tratamentos $(42,56,70,84$ e 98 dias no período da seca e 42, 60, 76, 91 e 105 dias no período das águas) e quatro repetições cada. Foram avaliadas características agronômicas, morfológicas e químicas. No período da seca verificou-se resposta quadrática significativa para altura de planta e comprimento de lâmina foliar. Para as demais características constatou-se resposta linear significativa, com exceção de diâmetro de colmo. No período das águas verificou-se resposta quadrática para comprimento de lâmina foliar, largura de lâmina foliar e relação folha: colmo. Para as demais características verificaram-se efeito linear significativo, com exceção de porcentagem de material senescente. Na seca verificou-se resposta linear das características químicas, exceto para proteína insolúvel em detergente neutro (\% MS). No período das águas, verificou-se resposta linear para todas as características avaliadas, exceto para proteína insolúvel em detergente ácido (\% PB). O capim-elefante BRS Canará para produção de forragem deve ser cortado entre 70 e 85 dias no período da seca e entre 60 e 70 dias no período das águas.

Palavras-chave: Composição morfológica. Época de colheita. Pennisetum purpureum. Produtividade de forragem.

\section{Introduction}

The tropical regions of Brazil generally have two distinct meteorological seasons: rainy, where humidity, temperature, and luminosity are generally favorable for the growth of tropical species; and dry, in which some or all of these factors became limiting, directly influencing the quantity and quality of forage produced. This seasonality is the biggest obstacle for the beef and dairy industry in Brazil (CARVALHO et al., 2018) because such variations imply a considerable limitation on animal performance during critical periods of the year.

To overcome the deficiencies during drought periods and balance the availability and demand for forage is through elephant grass cultivation for green chop feeding, which would allow for the roughage demand to be met during the dry season at a relatively low cost (ZAILAN et al., 2018). Among the main forages used as pasture, elephant grass (Pennisetum purpureum Shum.) has a relatively high yield and animal acceptability (CARVALHO et al., 2018), and can be used in the form of green chop feeding, silage, or hay (GIMENES et al., 2016).

Therefore, elephant grass has been used in several breeding programs, which allowed the introduction of the new cultivars (GIMENES et al., 2016). In 2012, through a partnership between EMBRAPA, EMPAER-MT, and UFMT, the elephant grass BRS Canará cultivar was released for cultivation in
Midwest Brazil, presenting higher yields than other existing cultivars. BRS Canará is characterized by its high size, semi-open grass clumps, green leaves and yellow sheathes, and stems of medium diameter with yellowish internodes. It has vegetative propagation through the stem and is indicated for green chop feeding use in the Amazon and Cerrado biomes (EMBRAPA, 2013a).

Fava (2008) evaluated the BRS Canará cultivar in Tangará da Serra-MT before commercial release and verified that it presented a higher annual production of 47,907 and 7,351 kg - DM.ha ${ }^{-1}$ in the rainy and dry seasons, respectively, than that of the other 14 clones tested. The lower seasonality observed in the BRS Canará cultivar could contribute to reduced production costs and may reduce the need for conserved forage use and concentrated feed during drought periods (ZAILAN et al., 2018).

In addition to the plant response in different seasons, the plant age at cutting time should be considered, as it considerably affects the quantity and especially quality of the harvested forage (CARVALHO et al., 2018). As the plant progresses through its phenological stages, the proportion of stems increases, that of leaves decreases, and the nutritive value decreases owing to the dilution of nutrients and increase of fibrous components (ZAILAN et al., 2018), which reflect negatively on animal intake. However, an increase in cutting age 
results in significant increases in dry matter (DM) production.

Therefore, it is essential to determine a cutting age that allows a balance between the qualitative and quantitative factors, and for this, it is necessary to study the agronomic, morphological, and chemical characteristics of elephant grass. Although there is considerable literature evaluating elephant grass in Southeast and South Brazil, there has been limited research in the Midwest. Furthermore, little is known about the production components and forage quality of new elephant grass cultivars; thus, the evaluation of new genotypes is essential to meet this demand (GIMENES et al., 2016). Therefore, the goal of the present study was to determine the ideal cutting age of BRS Canará elephant grass in the dry and rainy seasons for forage production.

\section{Materials and Methods}

The trial was carried out at the Experimental Farm of the Federal University of Mato Grosso, Santo Antônio de Leverger, MT, at $15^{\circ} 51^{\prime} \mathrm{S}$ and $56^{\circ} 04^{\prime} \mathrm{W}$, at an altitude of $140 \mathrm{~m}$, in the Baixada Cuiabana region. The meteorological data for the experimental period (March 2013 to February 2014) were collected at the Padre Ricardo Remetter Agrometeorological Station, which is part of the 9th DISME / INMET network, located approximately 1 $\mathrm{km}$ from the experiment site (Figure 1).

Figure 1. Monthly rainfall, average of minimum (Tmin), maximum (Tmax), and mean (Tmean) temperatures during the experimental period from March 2013 to February 2014.

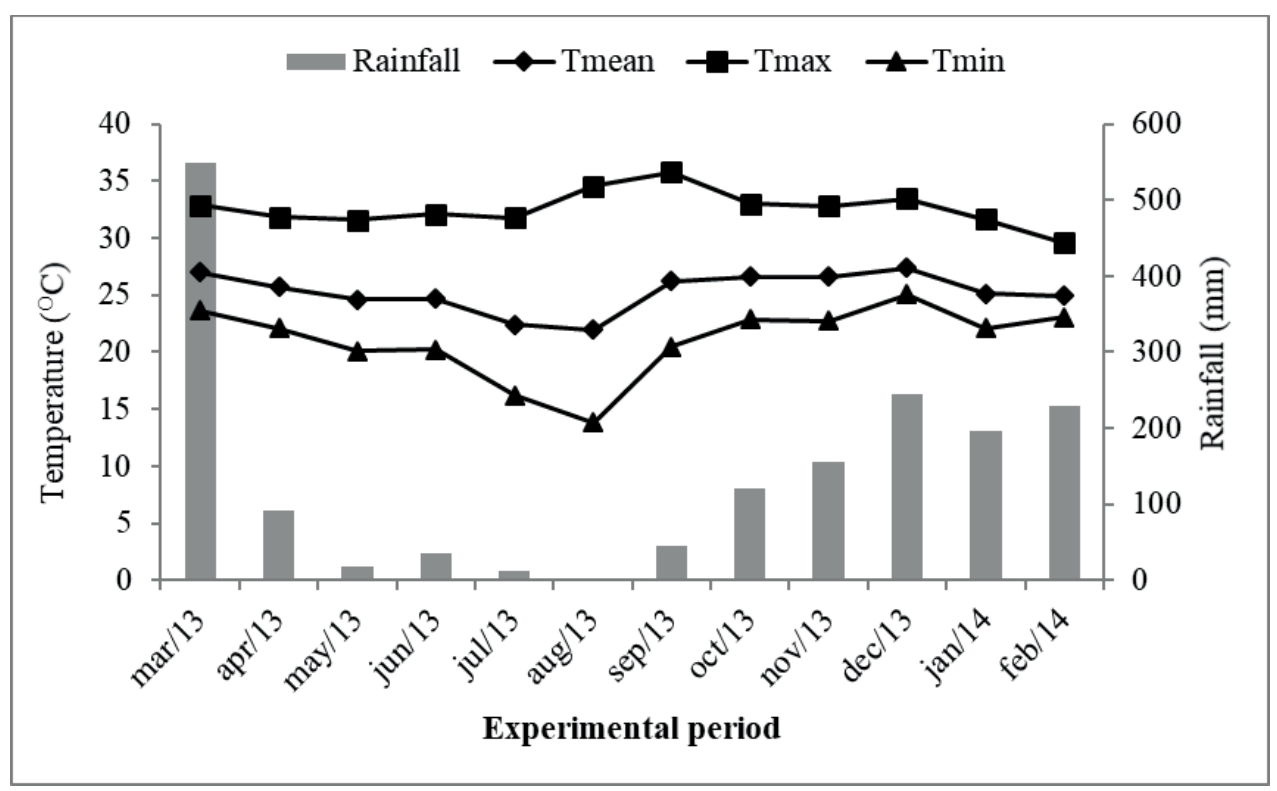

The climate of the region, according to the Köppen classification, is Aw, characterized by two well-defined seasons: dry (April to September) and rainy (October to March). The average monthly temperature varies from 22 to $27{ }^{\circ} \mathrm{C}$ and the rainfall is about $1,300 \mathrm{~mm}^{\text {year-1 }}{ }^{-1}$ The soil of the experimental area was classified as a Red Yellow Latosol with a Prominent A horizon (EMBRAPA, 2013b), or Oxisolo, according to the United States Soil Taxonomy Classification (USDA, 2014), with flat relief (Tables 1 and 2). 
Table 1. Chemical and physical properties of soil at a depth of $0-0.2 \mathrm{~m}$ in the experimental area.

\begin{tabular}{|c|c|c|c|c|c|c|c|c|c|c|c|c|c|}
\hline \multirow{2}{*}{$\mathrm{pH}\left(\mathrm{CaCl}_{2}\right)$} & $\mathrm{P}$ & $\mathrm{K}^{+}$ & $\mathrm{Ca}^{2+}$ & $\mathrm{Mg}^{2+}$ & $\mathrm{H}+\mathrm{Al}$ & $\mathrm{Al}^{3+}$ & $\mathrm{OM}$ & SB & CEC & $\mathrm{V}$ & Clay & Silt & Sand \\
\hline & \multicolumn{2}{|c|}{$\mathrm{mg} \mathrm{dm}{ }^{3}$} & \multicolumn{4}{|c|}{$\mathrm{cmol}_{\mathrm{c}} \mathrm{dm}^{3}$} & $\mathrm{~g} \mathrm{dm}^{3}$ & \multicolumn{2}{|c|}{$\mathrm{cmol}_{\mathrm{c}} \mathrm{dm}^{3}$} & $\%$ & \multicolumn{3}{|c|}{$\mathrm{g} \mathrm{kg}^{-1}$} \\
\hline 5.7 & 6.4 & 68.0 & 3.7 & 1.3 & 1.5 & 0.2 & 18.8 & 5.2 & 6.7 & 77.8 & 214.0 & 63.0 & 723.0 \\
\hline
\end{tabular}

pH: $\mathrm{CaCl}_{2}$; P e K: Mehlich-1 Extractor; $\mathrm{Ca}, \mathrm{Mg}, \mathrm{Al}: \mathrm{KCl} 1 \mathrm{~mol} \mathrm{~L}{ }^{-1}$ Extractor; $\mathrm{H}+\mathrm{Al}$ : SMP Extractor; O.M.: oxidation $\mathrm{Na}_{2} \mathrm{Cr}_{2} \mathrm{O}_{7}$ $0.67 \mathrm{~mol} \mathrm{~L}^{-1}+\mathrm{H}_{2} \mathrm{SO}_{4} 5 \mathrm{~mol} \mathrm{~L}{ }^{-1}$; clay, silt and sand: Pipette method, OM: organic matter; $\mathrm{SB}$ : sum of basis; CEC: cation exchange capacity; V: base saturation.

Table 2. Chemical and physical properties of soil at a depth of 0-0.1 $\mathrm{m}$ in the experimental area.

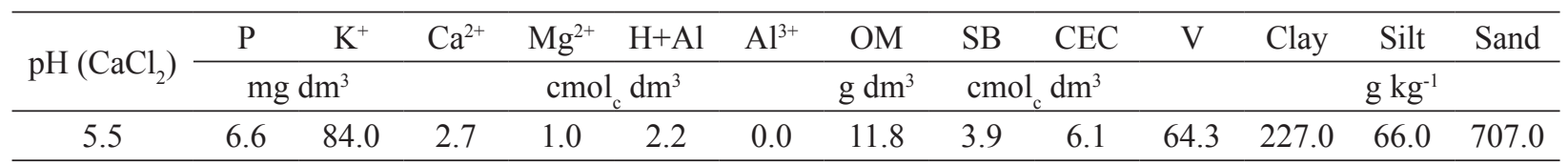

pH: $\mathrm{CaCl}_{2}$; P e K: Mehlich ${ }^{-1}$ Extractor; $\mathrm{Ca}, \mathrm{Mg}, \mathrm{Al}: \mathrm{KCl} 1$ mol L-1 Extractor; $\mathrm{H}+\mathrm{Al}$ : SMP Extractor; O.M.: oxidation $\mathrm{Na}_{2} \mathrm{Cr}_{2} \mathrm{O}_{7}$ $0.67 \mathrm{~mol} \mathrm{~L}^{-1}+\mathrm{H}_{2} \mathrm{SO}_{4} 5 \mathrm{~mol} \mathrm{~L}-1$; clay, silt and sand: Pipette method, OM: organic matter; $\mathrm{SB}$ : sum of basis; CEC: cation exchange capacity; $\mathrm{V}$ : base saturation.

The experimental design was in randomized blocks, with five treatments (cut ages) and four replicates each. During the dry season, the cut ages evaluated were: $42,56,70,84$, and 98 days, and in the rainy season: $42,60,76,91$, and 105 days. Each plot was $5 \mathrm{~m}$ long and $4 \mathrm{~m}$ wide, with spacing between rows of $1 \mathrm{~m}$. A central area of $3 \mathrm{~m}$ of the 2 central lines in each plot was considered a useful area, excluding a $1 \mathrm{~m}$ border around the whole plot.

The elephant grass cultivar BRS Canará was introduced in March 2013. At the implantation, 450 $\mathrm{kg} \square \mathrm{ha}^{-1}$ of single superphosphate was used. In May, before the drought period evaluations, a uniform cut was made at a height of $0.10 \mathrm{~m}$ from the ground, at 75 days after planting, followed by cover fertilization with $500 \mathrm{~kg} \square \mathrm{ha}^{-1}$ of NPK formulation 20-05-20. In November, prior to the start of the rainy season evaluations, a uniform cut was performed, followed by a coverage application of $500 \mathrm{~kg} \square \mathrm{ha}^{-1}$ of NPK 20-05-20.

At the respective cutting ages, the agronomic and morphological characteristics of the forage were measured. For the measurements, six tillers were cut at a height of $0.10 \mathrm{~m}$, distributed in the central lines of each plot. The agronomic characteristics evaluated were: plant height $(\mathrm{PH})$, which was obtained by measuring the lower base of the plant $(0.10 \mathrm{~m})$ to the insertion point of the last fully expanded leaf; leaf blade length (LL), which was measured on the last fully expanded leaf of each tiller; leaf blade width (LW), obtained in the middle (1/2 the length) of the leaf blade at the last fully expanded leaf; and stem diameter (SD), obtained at the base of the tiller, close to the soil.

For morphological characterization, the tillers were separated into leaves (LE), stems (ST) (stem + sheath), and dead material (DE; leaf blade with more than 50\% necrosis), identified and dried in a forced air ventilation oven with average temperature of $55-65^{\circ} \mathrm{C}$, for $72 \mathrm{~h}$. Subsequently, the percentage of leaves, stems, dead material, and leaf:stem ratio (LSR) were determined based on their DM content. To determine the forage dry mass (FP) yield, all the green mass of the useful area was harvested and corrected for their respective DM content.

After drying, the forage samples were ground in a Willey type mill, placed in plastic pots and subjected to analyses of DM, ash, and crude protein $(\mathrm{PB})$, according to the Association of Official Analytical Chemists (AOAC, 1990); neutral detergent insoluble protein (NDIP) and acid detergent insoluble protein (ADIP) were analyzed 
according to Licitra et al. (1996). The levels of acid detergent fiber (ADF) were determined according to Van Soest et al. (1994); indigestible neutral detergent fiber (iNDF) was determined according to Cochran et al. (1986), and the neutral detergent fiber free of ash and protein (NDFap) were determined according to Sniffen et al. (1992). The total digestible nutrient (TDN) and net lactation energy (NLE) levels were estimated according to Cappelle et al. (2001) and David (2001), respectively.

For statistical analysis, the following model was used:

$$
\begin{aligned}
& x_{i j}=m+t_{i}+b_{j}+e_{i j} \\
& i=1,2,3, \ldots, I \\
& j=1,2,3, \ldots, J
\end{aligned}
$$

where $\mathrm{x}_{\mathrm{ij}}=$ value observed in the plot that received treatment $\mathrm{i}$ in block $\mathrm{j}$ :

$\mathrm{m}=$ population mean;

$t_{i}=$ treatment effect $\mathrm{i}$ applied to the plot; $b_{j}=$ effect of block $j$, where the plot is;

$\mathrm{e}_{\mathrm{ij}}=$ effect of uncontrolled factors in the plot.

Data were submitted to analysis of variance and simple linear and quadratic regressions at the 5\% probability level using SAEG Statistical Software (1998).

\section{Results and Discussion}

The agronomic characteristics, morphological composition, and forage yield of elephant grass BRS Canará were influenced by the cutting ages in the dry season, except for the stem diameter $(\mathrm{P}>0.05)$ (Table 3). In the rainy season, all the agronomic characteristics, morphological compositions, and forage yield were influenced by the cutting ages (Table 4). In the drought period, we observed a quadratic response of the cut age on plant height, with maximum values of $122.58 \mathrm{~cm}$ for 94 days. In the rainy season, the plant height increased daily by $1.99 \mathrm{~cm}$.

Table 3. Plant height (PH), stem diameter (SD), leaf blade length (LL), leaf blade width (LW), percentage of leaf (LE),

\begin{tabular}{|c|c|c|c|c|c|c|c|c|}
\hline \multirow{2}{*}{ Variables } & \multicolumn{5}{|c|}{ Cutting ages (days) } & \multirow{2}{*}{ Regression Equation } & \multirow{2}{*}{$\begin{array}{l}\text { CV } \\
(\%)\end{array}$} & \multirow{2}{*}{$\mathrm{R}^{2}$} \\
\hline & 42 & 56 & 70 & 84 & 98 & & & \\
\hline \multicolumn{9}{|c|}{ Agronomic characteristics } \\
\hline $\mathrm{PH}^{1}$ & 41.44 & 86.97 & 103.09 & 117.18 & 123.50 & $\mathrm{y}=-134.9350+5.4938 \mathrm{x}-0.0293 \mathrm{x}^{2 * *}$ & 10.33 & 0.99 \\
\hline $\mathrm{LL}^{1}$ & 77.87 & 105.37 & 115.03 & 117.78 & 112.62 & $\mathrm{y}=-53.8551+4.2696 \mathrm{x}-0.0263 \mathrm{x}^{2 * *}$ & 3.14 & 0.99 \\
\hline $\mathrm{LW}^{1}$ & 2.53 & 3.03 & 3.32 & 3.71 & 3.85 & $\mathrm{y}=1.64075+0.0235893 \mathrm{x}^{* *}$ & 7.13 & 0.96 \\
\hline $\mathrm{SD}^{2}$ & 12.66 & 12.35 & 12.24 & 13.09 & 13.40 & $y=12.74$ & 6.49 & - \\
\hline \multicolumn{9}{|c|}{ Morphological composition } \\
\hline $\mathrm{LE}^{3}$ & 57.63 & 52.55 & 41.50 & 25.94 & 20.97 & $\mathrm{y}=89.6980-0.7139 x^{* *}$ & 5.64 & 0.96 \\
\hline $\mathrm{ST}^{3}$ & 40.51 & 44.27 & 54.28 & 62.66 & 66.38 & $\mathrm{y}=18.5583+0.5009 \mathrm{x} * *$ & 4.69 & 0.97 \\
\hline $\mathrm{DE}^{3}$ & 1.84 & 3.17 & 4.21 & 11.39 & 12.64 & $\mathrm{y}=-8.2562+0.2130 \mathrm{x} * *$ & 37.77 & 0.89 \\
\hline LSR & 1.42 & 1.18 & 0.76 & 0.41 & 0.31 & $\mathrm{y}=2.3156-0.0213 \mathrm{x}^{* *}$ & 7.52 & 0.96 \\
\hline \multicolumn{9}{|c|}{ Forage yield during the dry season } \\
\hline $\mathrm{DMY}^{4}$ & 4.08 & 7.37 & 10.27 & 12.02 & 12.24 & $y=-1284.06+149.794 x^{* *}$ & 18.32 & 0.91 \\
\hline
\end{tabular}
stem (ST) and dead material (DE), leaf:stem ratio (LSR), and yield of $\mathrm{DM} \mathrm{ha}^{-1}$ cut (DMY) of elephant grass BRS Canará at different cutting ages in the dry season.

${ }^{1}$ : $\mathrm{cm} ;{ }^{2}: \mathrm{mm} ;{ }^{3}$ : \%; ${ }^{4}$ : t DM ha ${ }^{-1}$ cut.

**, *: Significant at the 1 and $5 \%$ levels, respectively, by the $\mathrm{F}$ test.

$\mathrm{CV}$ : Coefficient of variation; $\mathrm{R}^{2}$ : Coefficient of determination. 
Bhering et al. (2008) evaluated the agronomic characteristics of elephant grass 'Roxo' at different ages of cut in Santo Antônio de Leverger, MT during the dry and rainy seasons, and also verified a positive linear response for plant height, varying from 100.06 (42 days) to $129.42 \mathrm{~cm}$ (98 days) during the dry season; and 122.03 (42 days) to $301.69 \mathrm{~cm}$
(105 days) in the rainy season. These results are greater than those found in the present study, for the dry season $(121.81 \mathrm{~cm})$ at 98 days, and rainy season $(209.06 \mathrm{~cm})$ at 105 days. The superior results found by Bhering et al. (2008), possibly occurred owing to higher phosphorus levels in the soil chemical composition than that in the present study.

Table 4. Plant height (PH), stem diameter (SD), leaf blade length (LL), leaf blade width (LW), percentage of leaf (LE), stem (ST) and dead material(DE), leaf:stem ratio (LSR), and yield of DM ha-1 cut (DMY) of elephant grass BRS Canará at different cutting ages in the rainy season.

\begin{tabular}{|c|c|c|c|c|c|c|c|c|}
\hline \multirow{2}{*}{ Variables } & \multicolumn{5}{|c|}{ Cutting ages (days) } & \multirow{2}{*}{ Regression Equation } & \multirow{2}{*}{$\mathrm{CV}(\%)$} & \multirow{2}{*}{$\mathrm{R}^{2}$} \\
\hline & 42 & 60 & 75 & 91 & 105 & & & \\
\hline \multicolumn{9}{|c|}{ Agronomic characteristics } \\
\hline $\mathrm{PH}^{1}$ & 64.38 & 120.25 & 151.38 & 178.46 & 204.12 & $y=-18.1275+2.1637 x^{* *}$ & 7.69 & 0.98 \\
\hline $\mathrm{L}^{1}$ & 93.79 & 118.96 & 122.17 & 111.08 & 107.00 & $y=-4.0264+3.2665 x-0.0213 x^{2 * *}$ & 5.31 & 0.88 \\
\hline $\mathrm{LW}^{1}$ & 3.36 & 4.46 & 4.43 & 4.34 & 4.10 & $y=-0.4388+0.1255 x-0.0008 x^{2 * *}$ & 5.26 & 0.90 \\
\hline $\mathrm{SD}^{2}$ & 14.33 & 15.62 & 15.69 & 15.74 & 16.13 & $y=13.6878+0.0242 x^{*}$ & 5.48 & 0.77 \\
\hline \multicolumn{9}{|c|}{ Morphological composition } \\
\hline $\mathrm{LE}^{3}$ & 50.48 & 35.40 & 29.75 & 24.41 & 19.08 & $\mathrm{y}=67.3172-0.4744 x^{* *}$ & 4.64 & 0.95 \\
\hline $\mathrm{ST}^{3}$ & 49.52 & 63.35 & 66.82 & 71.92 & 76.88 & $\mathrm{y}=35.2576+0.4069 \mathrm{x}^{* *}$ & 2.20 & 0.94 \\
\hline $\mathrm{DE}^{3}$ & 0 & 1.25 & 3.43 & 3.67 & 4.04 & $y=-2.5748+0.0675 x^{* *}$ & 34.61 & 0.91 \\
\hline LSR & 1.02 & 0.56 & 0.45 & 0.34 & 0.25 & $\mathrm{y}=1.3752-0.0113 \mathrm{x} * *$ & 5.24 & 0.89 \\
\hline \multicolumn{9}{|c|}{ Forage yield during the rainy season } \\
\hline DMY & 6.84 & 13.40 & 16.30 & 18.55 & 22.26 & $\mathrm{y}=-1.7754+0.2305 \mathrm{x}^{* *}$ & 5.72 & 0.97 \\
\hline
\end{tabular}

${ }^{1}: \mathrm{cm} ;{ }^{2}: \mathrm{mm} ;{ }^{3}: \% ;{ }^{4}: \mathrm{t} \mathrm{DM}$ ha ${ }^{-1}$ cut.

**, *: Significant at the 1 and 5\% levels, respectively, by the $\mathrm{F}$ test.

$\mathrm{CV}$ : Coefficient of variation; $\mathrm{R}^{2}$ : Coefficient of determination.

Gimenes et al. (2016) compared tillering density, forage mass, and agronomic characteristics in 12 elephant grass genotypes and observed heights ranging from 0.45 to $2.00 \mathrm{~m}$ at 90 days, which were similar to the values observed in the present study, both in dry and rainy seasons.

The lower values of height observed in the present study in the rainy season, compared to that of other research, possibly resulted from a delay at the beginning of the rains in the region, affecting the initial plant development. In addition, these results reinforced the observation by Fava (2008) when evaluating different clones of elephant grass in the commercial release phase, that the clone originating in BRS Canará presented a better DM production distribution during the year, which means it was superior to the other cultivars evaluated during the dry season.

The higher heights observed during the rainy season in relation to the dry period are a consequence of increased water availability. However, the higher heights owing to the cutting age indicated that the plants had a longer time to accumulate biomass. The maximum values estimated for leaf length were 121.20 and $119.30 \mathrm{~cm}$ found at 77 and 81 days, for the rainy and dry seasons, respectively. For leafblade 
width, the maximum value was $4.54 \mathrm{~cm}$ observed at 79 days in the rainy season. In the dry season, an increase of $0.02 \mathrm{~cm}$ per day was observed.

Silva et al. (2010) observed leaf blade length values between 67.00 and $102.50 \mathrm{~cm}$ for leaf 3 , and 68.00 and $99.50 \mathrm{~cm}$ for leaf 5 when evaluating the heritability of morphological characters in elephant grass clones in Pernambuco at 60 days of age. These values were lower than those found in the present study, which were $107.57 \mathrm{~cm}$ in the dry and 115.28 $\mathrm{cm}$ in the rainy season for the same age of cut, which was owing to the genotypic differences between the evaluated materials. For leaf blade width, Silva et al. (2010) verified values between 1.8 and $4.0 \mathrm{~cm}$ for leaf 3 and 2.00 and $3.80 \mathrm{~cm}$ for leaf 5, which were similar to those values observed in the present study, both for the dry $(2.53$ to $3.85 \mathrm{~cm})$ and rainy (3.36 to $4.43 \mathrm{~cm})$ season.

The quadratic responses observed for leaf blade length in the dry and rainy season occurred because in the regrowth phase, the leaves, which are responsible for light interception and photoassimilate production, are the first to be formed, promoting rapid leaf biomass accumulation. However, as the cutting age progresses, intraspecific competition for light increases, decreasing the quality and quantity of light reaching the interior canopy. At this moment, to ensure greater photosynthetic efficiency of the leaves, elephant grass invests in internode elongation to allocate its leaves at the top and maintain the structural balance of the canopy, the leaf blade length is reduced. Simultaneously, the apical meristem is elevated, and percentage of stems and dead material increases owing to greater shading.

Silva et al. (2010) verified that leaf blade length and width are related to leaf area index, which indicate the ability of the canopy to intercept sunlight for photosynthesis and generate energy for plant maintenance and growth. Similarly, the final leaf length is directly associated with plant height and stem length, and it seems that the leaf blade length increases with plant development to a maximum point, and then begins to decrease owing to the elevation of the apical meristem.

The stem diameter increased by $0.02 \mathrm{~mm}$ per day during the rainy period. Gimenes et al. (2016) observed values varying from 7.62 to $13.18 \mathrm{~mm}$ for elephant grass genotypes at 90 days, and these values were lower $(15.87 \mathrm{~mm})$ than those found in the present study in the rainy season, for the same cutting age. Bhering et al. (2008) verified a quadratic response of the cutting ages on stem diameter for both rainy and dry seasons, with maximum estimated values of $10.72 \mathrm{~mm}$ at 82 days in the dry and $13.20 \mathrm{~mm}$ at 87 days in the rainy season, both lower than those found in the present study, at both $82(15.68 \mathrm{~mm})$ and 87 days $(15.80 \mathrm{~mm})$.

The higher values found in the present study are possibly inherent differences between the cultivars in question, and the larger stem diameter of elephant grass BRS Canará may be one of the characteristics that explains its greater resistance to water stress in the dry season, based on observations in this study and also by Fava (2008), considering that larger diameter stems are more tolerant to drought, possibly owing to a greater content of reserves present in these components.

For leaf blade percentage, a daily decrease of $0.71 \%$ and $0.47 \%$ for the dry and rainy seasons, respectively, was observed. Similar results were found by Bhering et al. (2008), who observed a linear decrease in the rainy period by $0.60 \%$ per day, which was similar to the results found in the present study. In the dry period, the authors verified a quadratic effect of the cutting age on the leaf percentage, with a maximum value of $40.67 \%$ at 79 days.

At 60 days, Bhering et al. (2008) found leaf percentages of $40.21 \%$ and $51.18 \%$ for the dry and rainy seasons, respectively. Oliveira et al. (2017), evaluating forage production and nutritional quality of elephant grass 'Napier' in monoculture and integrated in the Cerrado/Pantanal, verified a 
$60.00 \%$ leaf percentage for elephant grass cut at 60 days in the rainy season. Carvalho et al. (2018) evaluated the irrigation effect on the agronomic characteristics in elephant grass 'Roxo' verified that leaf percentages varying from $57.17 \%$ to $48.14 \%$ at 60 days in water depths ranging from 0 to $700 \mathrm{~mm}$, respectively. For the 60 -day cutting age, similar results $(52.55 \%)$ were found during the dry season. For the rainy season, the results were lower $(35.40 \%)$ than those verified in the literature.

The leaf blade percentage variation verified in the literature occurred owing to edaphoclimatic differences of the environments where the experiments were performed. The tendency of this characteristic decrease was expected, but it is undesirable, considering that the leaf blade is a forage plant fraction fundamental for animal nutritional requirements (SILVA et al., 2010). In addition, this decrease in the percentage of leaf blades directly reflected a decrease of the leaf:stem ratio of the plant.

For stem percentage, a daily increase of $0.50 \%$ and $0.41 \%$ was verified, for the dry and rainy seasons, respectively. Similarly, Bhering et al. (2008) verified an increase in the stem percentage with the cutting age advancement in the rainy period. Oliveira et al. (2017) verified stem percentages ranging from $56.90 \%$ to 180 days in the dry and $25.70 \%$ to 60 days in the rainy season for elephant grass 'Napier', and the values found by these authors in the rainy season, smaller than those found in the present study for the dry season $(48.61 \%)$, as well as for rainy season $(59.67 \%)$.

The increased participation of this component in the forage morphological composition is associated with forage canopy development. During the regrowth period, the search for brightness between the tillers results in greater competition between them, resulting in increased stem numbers and sizes, and positioning the younger, more photosynthetically active leaves in higher canopy sites. This increase of stem height, and consequently plant height, demonstrates the importance of managing the canopy effectively to avoid reducing forage nutritive values.

The percentage of dead material also increased with the advancement of cutting age, increasing by $0.21 \%$ and $0.07 \%$ per day in the dry and rainy seasons, respectively. Oliveira et al. (2017) verified a dead material percentage of $17.20 \%$ at 180 days in the dry and of $14.30 \%$ at 60 days in the rainy season, which were greater than the results found in the present study, both for the dry (4.52\%), and rainy $(1.47 \%)$ season at the same cutting ages.

As with stem growth, dead material accumulation is associated with the advancement of the physiological maturity of elephant grass, which causes the oldest leaves to reach their time and die. Senescence owing to the advancement of plant age can also be explained by the greater vertical development of the canopy and shading of the lower leaves, which are left with a negative energy balance contributing increased respiration in the plant. Considering that forages present greater nutritive value in leaf blades, the cutting of elephant grass BRS Canará at an advanced age becomes disadvantageous owing to a decrease in the percentage of leaf blades and rapid increase in the percentage of stems and dead material.

For the leaf:stem ratio, a decrease of 0.21 and 0.07 per day were observed for the dry and rainy seasons, respectively. Zailan et al. (2018) evaluating the morphological and chemical composition of four cultivars of elephant grass with cutting ages between 6 and 8 weeks in Malaysia observed leaf:stem ratios of $0.74,1.06,1.84$, and 3.18 for Common Napier, Silver Napier, Red Napier, and Dwarf Napier cultivars, respectively. The results of the leaf:stem ratio obtained in the present work are within the range observed by Zailan et al. (2018) in the dry (1.42-1.18) and rainy season (1.02-0.74) for the same cutting age (6-8 weeks).

Wangchuk et al. (2015) compared three hybrids of elephant grass 'Napier' at three cutting ages (40, 
60, and 80 days) in Bhutan and observed the effect of the cutting age on the leaf:stem ratio, with a drastic decrease with the advancement of the cut. The leaf:stem ratio mean values for the Giant Napier hybrid were 4.50, 1.25, and 1.00, Pakchong-1 presented values of $4.80,0.82$, and 0.67 , and $\mathrm{CO}-3$ were $3.75,1.52$, and 1.20 , for the cutting ages of 40 , 60 , and 80 days, respectively. In the present study, the leaf:stem ratio was $1.46,1.04$, and 0.61 in the dry period, and $0.92,0.70$, and 0.47 in the rainy season at 40,60, and 80 days, respectively, for the same ages studied by Wangchuk et al. (2015).

This tendency was already expected, and as the cutting age approached the reproductive phase, the translocation of soluble carbohydrates from the stems and leaves to the inflorescences increased the lignin content and reduced the leaf:stem ratio, decreasing the quality (GIMENES et al., 2016). The leaf:stem ratio is fundamental when determining the appropriate time to cut the grass, as it affects the fiber content, which directly influences the forage digestibility and intake. According to Zailan et al. (2018), the leaf:stem ratio is an evaluation criterion for forage quality, considering that a high proportion of the leaves compared to stems indicates a better nutritive value of the same.

For forage yield, daily increases of 149.79 kg.DM.ha ${ }^{-1}$ in the dry and 230.53 kg.DM.ha ${ }^{-1}$ in the rainy seasons were observed. DM yield per cut was $57.91 \%, 56.72 \%, 56.08 \%, 55.67 \%$, and $55.40 \%$ higher in the rainy than that in the drought period, respectively for the studied ages. Zailan et al. (2018) verified yields from 3.36 to 5.82 t.DM.ha ${ }^{-1}$ per cut for ages 42-56 days, which were lower than those obtained in the present study, for both the dry 5.00 and 7.10 t.DM.ha ${ }^{-1}$, and rainy 7.90 and 11.13 t.DM. $\mathrm{ha}^{-1}$ seasons, respectively.

Gimenes et al. (2016) observed productivity ranging from 2.23 to 5.90 t.DM.ha ${ }^{-1}$ for different elephant grass genotypes cut at 90 days, which were lower than those found in the present study, both during the dry (12.20 t.DM.ha-1), and rainy (18.97
t.DM.ha ${ }^{-1}$ ) seasons for the same cutting age. The higher productivity results obtained in the present study demonstrated that there was no relevant light or nutritional restrictions in the experimental area; in addition, they confirmed the great productive potential of BRS Canará. It is possible the higher yield obtained with the advancement of cutting age was owing to the longer time for biomass accumulation in the plant structure.

In forage regrowth, there is a greater growth of leaves; however, as the canopy reestablishes, autoshading of the crop occurs, which decreases leaf blade accumulation and increases stem and dead material accumulation. Therefore, it could be inferred that larger cutting ages underutilize forage productive and qualitative potential, by reducing the number of cuts per year.

The results of the morphological composition demonstrated that the best cutting age for elephant grass BRS Canará in the dry season is from 70 to 85 days, presenting a height of 106.06-120.35 cm, leaf length of 116.15-119.04 cm, leaf width of 3.29$3.64 \mathrm{~cm}$, leaf percentages of $39.72 \%-29.02 \%$, stems percentages of $53.62 \%-61.13 \%$, dead material of $6.65 \%-9.85 \%$, leaf:stem ratio of $0.82-0.51$, and forage yield of 9.20-11.44 t.DM.ha ${ }^{-1}$. During the rainy season, the best morphological composition of elephant grass BRS Canará was obtained from 60 to 70 days, presenting a height of 111.69-133.33 $\mathrm{cm}$, leaf length of $115.28-120.26 \mathrm{~cm}$, leaf width diameter of 4.21-4.43 cm, stem diameter of 15.14$15.38 \mathrm{~mm}$, leaf percentages of $38.85 \%-34.11 \%$, stem percentages of $59.67 \%-63.74 \%$, dead material of $1.47 \%-2.15 \%$, leaf:stem ratio of $0.70-0.58$, and forage yield of 12.05-14.36 t.DM.ha-1.

During the dry season, there was a linear response for all the chemical characteristics evaluated, except indigestible protein in neutral detergent (\% DM) (Table 5). In the rainy season, a linear response was verified for all evaluated characteristics, except for indigestible protein in acid detergent (\% CP) (Table 6). 
Table 5. Dry matter (DM), ash, neutral detergent fiber (NDF), acid detergent fiber (ADF), indigestible neutral detergent fiber (iNDF), corrected neutral detergent fiber for ash and protein (NDFap), crude protein (CP), neutral detergent insoluble protein in DM (NDIP DM), neutral detergent insoluble protein in CP (NDIP CP), acid detergent insoluble protein in DM (ADIP DM), acid detergent insoluble protein in CP (ADIP CP), total digestible nutrients (TDN), and net lactation energy (NLE) of elephant grass BRS Canará at different cutting ages in the dry season.

\begin{tabular}{|c|c|c|c|c|c|c|c|c|}
\hline \multirow{2}{*}{ Variables } & \multicolumn{5}{|c|}{ Cutting age } & \multirow{2}{*}{ Regression Equation } & \multirow{2}{*}{$\mathrm{CV}(\%)$} & \multirow{2}{*}{$\mathrm{R}^{2}$} \\
\hline & 42 & 56 & 70 & 84 & 98 & & & \\
\hline \multicolumn{9}{|c|}{ Agronomic characteristics } \\
\hline $\mathrm{DM}^{1}$ & 15.98 & 19.62 & 20.35 & 22.26 & 23.11 & $\mathrm{y}=11.8103+0.120807 \mathrm{x}^{* *}$ & 8.73 & 0.92 \\
\hline $\mathrm{ASH}^{2}$ & 15.94 & 14.30 & 12.68 & 11.65 & 10.12 & $y=20.0848-0.102056 x^{* *}$ & 8.03 & 0.99 \\
\hline $\mathrm{ADF}^{2}$ & 38.07 & 39.80 & 44.78 & 46.56 & 48.13 & $\mathrm{y}=30.0182+0.192130 \mathrm{x} * *$ & 4.00 & 0.95 \\
\hline $\mathrm{iNDF}^{2}$ & 17.12 & 21.78 & 26.21 & 29.15 & 32.11 & $y=6.60041+0.266811 x^{* *}$ & 7.67 & 0.98 \\
\hline NDFap $^{2}$ & 55.08 & 59.71 & 66.19 & 68.34 & 71.96 & $\mathrm{y}=43.0648+0.302742 \mathrm{x} * *$ & 3.46 & 0.97 \\
\hline $\mathrm{CP}^{2}$ & 13.43 & 10.15 & 9.00 & 7.73 & 6.63 & $y=17.3971-0.114381 x^{* *}$ & 4.50 & 0.93 \\
\hline NDIP DM² & 3.16 & 3.03 & 2.96 & 2.96 & 2.91 & $y=3.00$ & 9.90 & - \\
\hline $\mathrm{NDIP} \mathrm{CP}^{3}$ & 23.76 & 29.90 & 33.16 & 38.04 & 44.35 & $\mathrm{y}=9.17989+0.352318 \mathrm{x} * *$ & 16.36 & 0.99 \\
\hline ADIP DM² & 1.39 & 1.22 & 1.09 & 1.03 & 0.96 & $\mathrm{y}=1.65893-0.00743349 \mathrm{x} * *$ & 14.71 & 0.95 \\
\hline $\mathrm{ADIP} \mathrm{CP}^{3}$ & 10.32 & 11.99 & 12.19 & 13.20 & 14.64 & $\mathrm{y}=7.54949+0.0702391 \mathrm{x}^{* *}$ & 15.97 & 0.95 \\
\hline $\mathrm{TDN}^{2}$ & 59.25 & 57.90 & 54.01 & 52.63 & 51.40 & $y=65.5159-0.149669 * *$ & 2.46 & 0.95 \\
\hline NLE & 1.32 & 1.28 & 1.14 & 1.09 & 1.04 & $\mathrm{y}=1.54949-0.00537965^{* *}$ & 4.15 & 0.95 \\
\hline
\end{tabular}

1: \% of total mass; ${ }^{2}: \%$ of DM; ${ }^{3}: \%$ of CP.

**, *: Significant at the 1 and $5 \%$ levels, respectively, by the $\mathrm{F}$ test.

$\mathrm{CV}$ : Coefficient of variation; $\mathrm{R}^{2}$ : Coefficient of determination.

Table 6. Dry matter (DM), ash, neutral detergent fiber (NDF), acid detergent fiber (ADF), indigestible neutral detergent fiber (iNDF), corrected neutral detergent fiber for ash and protein (NDFap), crude protein (CP), neutral detergent insoluble protein in DM (NDIP DM), neutral detergent insoluble protein in CP (NDIP CP), acid detergent insoluble protein in DM (ADIP DM), acid detergent insoluble protein in CP (ADIP CP), total digestible nutrients (TDN), and net lactation energy (NLE) of elephant grass BRS Canará at different cutting ages in the rainy season.

\begin{tabular}{|c|c|c|c|c|c|c|c|c|}
\hline \multirow{2}{*}{ Variables } & \multicolumn{5}{|c|}{ Cutting age } & \multirow{2}{*}{ Regression Equation } & \multirow{2}{*}{$\mathrm{CV}(\%)$} & \multirow{2}{*}{$\mathrm{R}^{2}$} \\
\hline & 42 & 60 & 75 & 91 & 105 & & & \\
\hline \multicolumn{9}{|c|}{ Agronomic characteristics } \\
\hline $\mathrm{DM}^{1}$ & 18.90 & 20.73 & 21.89 & 23.40 & 26.35 & $\mathrm{y}=13.9439+0.111081 \mathrm{x}^{* *}$ & 3.99 & 0.97 \\
\hline $\mathrm{ASH}^{2}$ & 12.31 & 10.57 & 9.44 & 8.92 & 7.69 & $\mathrm{y}=15.1330-0.0734420 * *$ & 11.17 & 0.97 \\
\hline $\mathrm{ADF}^{2}$ & 40.67 & 42.03 & 42.87 & 46.26 & 48.52 & $\mathrm{y}=34.6433+0.129471^{* *}$ & 5.28 & 0.89 \\
\hline $\mathrm{iNDF}^{2}$ & 20.16 & 24.99 & 28.13 & 35.06 & 36.02 & $y=9.36928+0.267891 * *$ & 10.57 & 0.88 \\
\hline NDFap $^{2}$ & 57.70 & 62.18 & 64.61 & 70.46 & 73.38 & $\mathrm{y}=46.8903+0.257923 \mathrm{x} * *$ & 4.48 & 0.93 \\
\hline $\mathrm{CP}^{2}$ & 11.93 & 9.12 & 8.10 & 7.18 & 6.03 & $\mathrm{y}=15.1904-0.0922957 \mathrm{x} * *$ & 5.37 & 0.93 \\
\hline NDIP DM ${ }^{2}$ & 3.52 & 3.28 & 3.27 & 3.22 & 3.17 & $y=3.67469-0.00521972 x^{*}$ & 5.22 & 0.81 \\
\hline NDIP $\mathrm{CP}^{3}$ & 29.64 & 35.89 & 40.22 & 44.74 & 52.77 & $\mathrm{y}=13.7561+0.369441 \mathrm{x}^{* *}$ & 5.86 & 0.98 \\
\hline ADIP DM ${ }^{2}$ & 1.31 & 1.03 & 1.01 & 0.94 & 0.83 & $y=1.54183-0.00712673 x * *$ & 17.97 & 0.89 \\
\hline $\mathrm{ADIP} \mathrm{CP}^{3}$ & 10.99 & 11.39 & 12.48 & 13.05 & 13.74 & $y=12.33$ & 19.63 & - \\
\hline $\mathrm{TDN}^{2}$ & 57.22 & 56.16 & 55.50 & 52.86 & 51.10 & $y=61.9129-0.100858 x^{* *}$ & 3.32 & 0.89 \\
\hline NLE & 1.25 & 1.21 & 1.19 & 1.09 & 1.03 & $\mathrm{y}=1.41999-0.00362519 \mathrm{x}^{* *}$ & 5.64 & 0.89 \\
\hline
\end{tabular}

${ }^{1}: \%$ of total mass; ${ }^{2}: \%$ of DM; ${ }^{3}: \%$ of CP.

**, *: Significant at the 1 and $5 \%$ levels, respectively, by the $\mathrm{F}$ test.

$\mathrm{CV}$ : Coefficient of variation; $\mathrm{R}^{2}$ : Coefficient of determination. 
There was a daily increase of $0.12 \%$ and $0.11 \%$ in the forage DM content in the dry and rainy seasons, respectively. Oliveira et al. (2017) verified DM levels of $37.93 \%$ and $31.18 \%$ for elephant grass 'Napier' cut at 180 and 60 days in the dry and rainy seasons, respectively, with higher values than those found in the present study. In contrast, Martins-Costa et al. (2008) evaluated the chemical composition of elephant grass in different ages of cut and observed a negative linear effect on the DM content with increasing age of cut, decreasing from $16.95 \%$ to $13.14 \%$, from 42 to 105 days, during the rainy period.

The results presented by Sá et al. (2010) evaluating the fractionation of carbohydrates and proteins of tropical grasses in different cutting ages corroborate those found in the present study, demonstrating that the DM content increased with the advancement of cut ages. According to the authors, these results indicated that the age of cut is a management factor that contributes to determining forage production and quality. With plant aging, the moisture content decreases, resulting in higher DM content, which influence forage intake (SÁ et al., 2010).

There was a daily decrease of $0.10 \%$ and $0.07 \%$ in the ash content for the dry and rainy seasons, respectively. Similarly, Martins-Costa et al. (2008) observed a reduction from $14.32 \%$ to $6.46 \%$, from 30 to 105 days, respectively, during the rainy period. Oliveira et al. (2017) observed ash content of $7.71 \%$ and $5.47 \%$ for elephant grass cut at 60 and 180 days, respectively, also showing that with the advancement of cutting age, the ash concentration in the plants was reduced. This decrease in ash content can negatively affect animals, resulting in decreased performance and increased incidence of health problems (VAN SOEST, 1994).

The levels of ADF, iNDF, and NDFap increased daily by of $0.19 \%, 0.26 \%$, and $0.30 \%$ in the dry season and $0.13 \%, 0.26 \%$, and $0.25 \%$ in the rainy season, respectively. Martins-Costa et al. (2008) observed a quadratic response for ADF content as a function of cutting age, with a maximum value observed at 55 days, and found a linear response of the cut age on the iNDF content, increasing from $18.76 \%$ at 30 days to $33.88 \%$ at 105 days, with a daily increase of $0.20 \%$, which was lower than that found in the present study, for both periods $(0.26 \%)$.

Concurring with the results obtained in the present study, Sá et al. (2010) observed an increase in ADF values with the advancement of the cutting age. These authors also observed a relationship between the cut ages and NDFap, with characteristic NDFap increases as the cutting age progressed. Zailan et al. (2018) observed ADF levels varying between $36.00 \%$ and $42.15 \%$ for different elephant grass cultivars with 42 to 56 days, which were within the range found in the present study, both for the dry (38.07\% to $39.80 \%)$ and rainy $(40.67 \%$ to $41.89 \%$ ) season, respectively, for the same age range evaluated.

These results were expected, considering that the major changes occurring in the chemical composition of forage plants are those resulting from their maturation. As the plant ages, the proportion of potentially digestible components tends to decrease and fiber content increases (MARTINS-COSTA et al., 2008). This increase in the percentage of iNDF with the advancement of the cutting age indicated a reduction in the proportion of forage that could be digested by animals (MARTINS-COSTA et al., 2008).

There was a daily decrease in protein content of 0.11 and 0.09 for the dry and rainy seasons, respectively. There was also a significant linear effect for NDIP (DM basis) in the rainy period, with a daily decrease of 0.0052 . During the drought period, the NDIP (DM basis) content decreased from 3.16 to 2.91 , from 42 days to 98 days, but there was no significant effect. There was also a daily decrease of 0.007 for ADIP (DM basis), both for the dry and rainy season.

Until the age of 91 days in the dry season, and up to 89 days in the rainy season, elephant grass forage remained above the $7 \%$ recommended by 
Van Soest (1994) as the minimum necessary to maintain rumen microbial activity. Thus, it can be inferred that cuts of the elephant grass BRS Canará should be performed in lower ages than these, as levels below $7 \%$ affect digestibility and limit forage intake; thus, resulting in low animal productivity (VAN SOEST, 1994).

Martins-Costa et al. (2008) verified a linear reduction in CP levels of elephant grass from $17.14 \%$ at 30 days to $8.73 \%$ at 105 days, with a decrease of $0.11 \%$ per day, similar to that obtained in the present study for both periods. As the plant advances its stage of maturation, there is a decrease in the CP content as a function of the fiber content increase in the plant tissues, resulting in a decrease in the nutritive value of the elephant grass (MARTINSCOSTA et al., 2008). Sá et al. (2010) found a decrease in CP content with cutting age increase in all grasses evaluated. Oliveira et al. (2017) found CP levels of $3.29 \%$ and $7.11 \%$ for elephant grass cut at 180 and 90 days, respectively for the dry and rainy seasons.

There was a linear increase in NDIP (CP basis) with daily increment of $0.35 \%$ and $0.37 \%$ for the dry and rainy seasons, respectively. Similarly, ADIP (CP basis) also increased linearly during the dry season, with a daily increase of 0.07 . Concurring with the results of the present study, Martins-Costa et al. (2008) also verified a daily increase in ADIP (CP basis) with the advance in cutting ages, increasing $0.06 \%$, from 42 to 98 days. Sá et al. (2010) also found that NDIP (CP basis) levels increased linearly with the advancement of the cutting age.

These authors suggested that younger cut ages should be used for feeding more demanding animals. It is possible that the increase in cutting age greatly compromises protein utilization in ruminant feed, and the higher the NDIP or ADIP percentages, the slower the protein in a food will be degraded. Based on these results, it is possible that higher cutting ages lead to decreased CP content, increasing the amount of protein bound to the fibrous components, which is undesirable.

The TDN content decreased daily by $0.14 \%$ and $0.10 \%$ in the dry and rainy seasons, respectively. Similarly, the net lactation energy decreased by 0.005 and 0.003 per day for the dry and rainy seasons, respectively. Martins-Costa et al. (2008) verified that the TDN content was quadratically affected by cutting age, with a maximum value of $57.21 \%$ at 49 days, similar to the results obtained in this work at the same cutting age, both during the dry (58.18\%) and rainy (56.97\%) season.

The results of the chemical composition obtained in the present study demonstrated that the best age for cutting elephant grass BRS Canará in the dry season was between 70 and 85 days, resulting in $20.27 \%$ $22.08 \%$ DM, $12.94 \%-11.41 \%$ ash, $43.47 \%-46.35 \%$ ADF, 25.28\%- 29.28\% iNDF, 64.26\%-68.80\% NDFap, 9.39\%- 7.67\% CP, 33.84\%-39.13\% NDIP (CP basis), 1.14-1.03 ADIP (DM basis), 12.47\%13.52\% ADIP (CP basis), $55.04 \%-52.79 \%$ TDN, and 1.17- 1.09 NLE.

In the rainy season, the best cutting age for elephant grass BRS Canará was between 60 and 70 days, resulting in 20.61\%-21.72\% DM, $10.73 \%$ 9.99\% ash, $42.41 \%-43.70 \%$ ADF, $25.44 \%-28.12 \%$ iNDF, 62.37\%- 64.94\% NDFap, 65\%-8.73\% CP, $3.36 \%-3.31 \%$ NDIP (DM basis), 35.92\%- 39.62\% NDIP (CP basis), 1.11- 1.04 ADIP (DM basis), $55.86 \%-54.85 \%$ TDN, and 1.20- 1.17 NLE.

At these cutting ages, the grass presents the best relationship between the agronomic, morphological, and chemical characteristics. It can also be affirmed that elephant grass presents great productive and qualitative potential for use in the Midwest region of Brazil, both during the dry and rainy seasons. However, the cutting age of the grass may vary according to the edaphoclimatic conditions of each region, given that these conditions are determinant for the plant development, and consequently its morphological and chemical composition. 


\section{Conclusions}

Elephant grass BRS Canará grown for forage production should be cut between 70 and 85 days in the dry season and between 60 and 70 days in the rainy season.

\section{References}

ASSOCIATION OF OFFICIAL ANALYTICAL CHEMISTS - AOAC. Official methods of analysis. $12^{\text {th }}$ ed. Washington, D.C., 1990. 1015 p.

BHERING, M.; CABRAL, L. S.; ABREU, J. G.; SOUZA, A. L.; ZERVOUDAKIS, J. T.; RODRIGUES, R. C.; PEREIRA, G. A. C.; REVERDITO, R.; OLIVEIRA, Í. S. Características agronômicas do capim-elefante roxo em diferentes idades de corte na Depressão Cuiabana. Revista Brasileira de Saúde e Produção Animal, Salvador, v. 9. n. 3, p. 384-396, 2008.

CAPPELLE, E. R.; VALADARES FILHO, S. C.; SILVA, J. F. C.; CECON, P. R. Estimativas do valor energético a partir de características químicas e bromatológicas dos alimentos. Revista Brasileira de Zootecnia, Viçosa, MG, v. 30 , n. 6 , p. $1837-1856,2001$. DOI: $10.1590 /$ S151635982001000700022

CARVALHO, A. P. S.; ARRUDA, R. M.; ABREU, J. G.; SOUZA, A. L.; RODRIGUES, R. C.; LIMA, L. R.; CABRAL, L. S.; BEHLING NETO, A. Agronomic features of elephant grass (Pennisetum purpureum Schum) cv. Roxo under irrigation. Semina: Ciências Agrárias, Londrina, v. 39, n. 1, p. 275-286, 2018. DOI: $10.5433 / 1679-0359.2018 \mathrm{v} 39 \mathrm{n} 1 \mathrm{p} 275$

COCHRAN, R. C.; ADAMS, D. C.; WALLACE, J. D.; GALYEAN, M. L. Predicting digestibility of different diets with internal markers. Journal Animal Science, Champaign, v. 63 , n. 5, p. 1476-1483, 1986. DOI: $10.2527 /$ jas $1986.6351476 \mathrm{x}$

DAVID, F. M. Composição e degradabilidade, através da técnica de produção de gás, de quatro gramíneas tropicais submetidas a corte em diferentes idades. 2001. Dissertação (Mestrado em Zootecnia) - Universidade Federal de Lavras, Lavras.

EMPRESA BRASILEIRA DE PESQUISA AGROPECUÁRIA - EMBRAPA Cerrados. Integração. Jornal eletrônico do ILPF. ed. 11. Ano 4. Planaltina, DF: José Heitor Vanconcelos, fev. 2013a. Disponível em: http://boletimilpf.cnpms.embrapa.br/noticia. php?ed $=\mathrm{MTE}=\& \mathrm{id}=\mathrm{NDM}=$. Acesso em: 17 jul. 2018.
EMPRESA BRASILEIRA DE PESQUISA AGROPECUÁRIA - EMBRAPA. Sistema brasileiro de classificação de solos. 3. ed. Brasília, DF: Embrapa Solos, 2013b. 353 p.

FAVA, A. Distribuição estacional da produção de clones de capim-elefante (Pennisetum pupureum Schum.) para utilização como capineira no cerrado matogrossense. 2008. Dissertação (Mestrado em Agricultura Tropical) Universidade Federal de Mato Grosso, Cuiabá.

GIMENES, F. M. A.; BERNDT, A.; MATEUS, G. P.; LÉDO, F. J. S.; DEMARCHI, J. J. A. A.; GIACOMINI, A. A.; GERDES, L.; BATISTA, K. Forage mass and agronomic traits of Elephant Grass genotypes under free-growth and conventional cutting systems. Semina: Ciências Agrárias, Londrina, v. 37 , n. 4 , p. 2577-2588, 2016. Suplemento 1. DOI: 10.5433/1679-0359.2016v37n4Supl1p2577

LICITRA, G.; HERNANDEZ, T. M.; VAN SOEST, P. J. Standartization of procedures for nitrogen fractionation of ruminant feeds. Animal Feed Science and Technology, Amsterdam, v. 57, n. 4, p. 347-358, 1996. DOI: 10.1016/0377-8401(95)00837-3

MARTINS-COSTA, R. H. A; CABRAL, L. S.; BHERING, M.; ABREU, J. G.; ZERVOUDAKIS, J. T.; RODRIGUES, R. C.; OLIVEIRA, I. S. Valor nutritivo do capim-elefante obtido em diferentes idades de corte. Revista Brasileira de Saúde e Produção Animal, Salvador, v. 9, n. 3, p. 397-406, 2008.

OLIVEIRA, M. V. M.; DEMEU, A. A.; BONATTI, F. K. Q.; TORRES, F. E.; TEODORO, P. E. Production and quality of forage under intercropping systems in the Cerrado/Pantanal Ecotone. Bioscience Journal, Uberlândia, v. 33, n. 2, p. 341-348, 2017. DOI: 10.14393/ BJ-v33n2-32880

SÁ, J. F.; PEDREIRA, M. S.; SILVA, F. F.; BONOMO, P.; FIGUEIREDO, M. P.; MENEZES, D. R.; ALMEIDA, T. B. Fracionamento de carboidratos e proteínas de gramíneas tropicais cortadas em três idades. Arquivo Brasileiro de Medicina Veterinária e Zootecnia, Belo Horizonte, v. 62, n. 3, p. 667-676, 2010. DOI: 10.1590/ S0102-09352010000300023

SILVA, A. L. C.; SANTOS, M. V. F.; DUBEUX JUNIOR, J. C. B.; LIRA, M. A.; FERREIRA, R. L. C.; FREITAS, E. V.; CUNHA, M. V.; SILVA, M. C. Variabilidade e herdabilidade de caracteres morfológicos em clones de capim- elefante na Zona da Mata de Pernambuco. Revista Brasileira de Zootecnia, Viçosa, MG, v. 39, n. 10, p. 2132 2140, 2010. DOI: 10.1590/S1516-35982010001000005 
SISTEMA DE ANÁLISES ESTATÍSTICAS E VAN SOEST, P. J. Nutritional ecology of the ruminant. GENÉTICAS - SAEG. Manual do usuário. Versão 8.1. 2. 2d. Ithaca: Comstock Publishing Associates/ Cornell Viçosa, MG: Fundação Arthur Bernardes - UFV, 1998. $150 \mathrm{p}$.

SNIFFEN, C. J.; O'CONNOR, D. J.; VAN SOEST, P. J.; FOX, D. G.; RUSSELL, J. B. A net carbohydrate and protein system for evaluating cattle diets: carbohydrate and protein availability. Journal of Animal Science, Champaign, v. 70 , n. 12 , p. $3562-3577,1992$. DOI: $10.2527 / 1992.70113562 x$

UNITED STATES DEPARTMENT OF AGRICULTURE - USDA. Keys to soil taxonomy. $12^{\text {th }}$ ed. Washington: USDA-Natural Resources Conservation Service, 2014. University, 1994. 476 p.

WANGCHUK, K.; RAI, K.; NIROLA, H.; THUKTEN; DENDUP, C.; MONGAR, D. Forage growth, yield and quality responses of Napier hybrid grass cultivars to three cutting intervals in the Himalayan foothills. Tropical Grasslands - Forrajes Tropicales, Cali, v. 3, n. 3, p. 142150, 2015. DOI: $10.17138 /$ TGFT(3)142-150

ZAILAN, M. Z.; YAAKUB, H.; JUSOH, S. Yield and nutritive quality of Napier (Pennisetum purpureum) cultivars as fresh and ensiled fodder. The Journal of Animal \& Plant Sciences, Lahore, v. 28, n. 1, p. 63-72, 2018. 